Vol. 14 (2005): 189-201.

\title{
Weed flora and weed management of field peas in Finland
}

\author{
Jukka Salonen, Terho Hyvönen and Heikki Jalli \\ MTT Agrifood Research Finland, Plant Production Research, FI-31600 Jokioinen, Finland \\ e-mail: jukka.salonen@mtt.fi
}

\begin{abstract}
The composition of the weed flora of dry pea (Pisum sativum L.) fields and cropping practices were investigated in southwestern Finland. Surveys were done in 2002-2003 in 119 conventionally cropped fields and 64 fields under organic cropping. Herbicides were applied to $92 \%$ of conventionally cropped fields where they provided relatively good control but were costly. Weeds were controlled mechanically only in five fields under organic production. A total of 76 weed species were recorded, of which 29 exceeded the $10 \%$ frequency level of occurrence. The average number of weed species per field was 10 under conventional cropping and 18 under organic cropping. The most frequent weed species in both cropping practices were Chenopodium album, Stellaria media and Viola arvensis. Elymus repens was the most frequent grass species. The difference in species composition under conventional and organic cropping was detected with Redundancy Analysis. Under conventional cropping, features of crop stand and weed control explained $38.7 \%$ and $37.6 \%$ of the variation respectively. Under organic cropping the age of crop stand and field location (y co-ordinate) respectively explained best the variation. Weeds could be efficiently managed with herbicides under conventional cropping, but they represented a significant problem for organic production. Mixed cultivation of pea with cereals is recommended, particularly for organic cropping, as it favours crop competition against weeds.
\end{abstract}

Key words: biodiversity, bentazone, herbicides, metribuzin, organic farming, Pisum sativum, Redundancy Analysis, variation partitioning, weeds, weed control

\section{Introduction}

Pea (Pisum sativum L.) is a minor field crop grown only on about 5000 hectares corresponding roughly to $0.25 \%$ of the cultivated field area in Finland
(Ministry of Agriculture and Forestry 2004). About $34 \%$ of that dry pea area was under certified organic production in 2002-2003. Combine-harvested field pea is grown for human consumption, animal feed or seed for sowing. Peas are often grown in a rotation with cereals and also mixed with cere- 
als, particularly with oats (Avena sativa L.) and typically on organic farms. Cereal-dominated crop rotation is typical of conventional farms in southwestern Finland, whereas organic crop production aims at more diverse crop sequences. Dry pea production would provide conventional farms in particular with an excellent alternative crop, but the uncertainty of harvest under rainy conditions in August and high production costs (seed, crop protection, drying) limit expansion of pea cultivation.

A research programme, "Pea as a source for domestic protein", was launched in 2002 in Finland to improve crop reliability and economics of pea production through better management. A subproject of the research programme, a survey of diseases, pests and weeds in pea fields, was carried out in 2002-2003. The objective was to establish the major targets for crop protection in order to define control recommendations, particularly in the case of possible marked expansion in pea production. In addition, the current crop management and crop protection practices for pea cultivation were investigated by interviewing farmers.

Published information on diseases, insect pests and weeds of pea fields in Finland is sparse. Recent weed research activities have been directed at herbicide testing in field pea (Ruuttunen 1999). On the other hand, there are detailed descriptions of the weed flora in spring cereals from the late 1990s (Salonen et al. 2001a, b). Earlier, an inventory of weeds in organically cultivated cereal fields was carried out on 40-48 farms visited annually in 1984-1986 (Mela 1988).

This paper focuses on the results of a weed survey with two specific aims. First, we aimed to study the general patterns of weed community species composition in relation to crop management in all fields examined. Secondly, we analysed weed communities in conventionally and organically cropped fields separately, aiming to explore the relative importance of different cropping measures as well as other factors explaining the variation in weed species composition. We expected that the application of herbicides with various active ingredients would be of central importance in conventionally cropped fields, while in organically cropped fields the variation would be explained with various cropping measures of more equal importance.

\section{Material and methods}

\section{Study regions, farms and fields}

The weed survey was carried out in southwestern Finland in 2002-2003 (Fig. 1). The survey regions and farms were randomly selected using national statistics on pea cultivation from previous years provided by the Information Centre of the Ministry of Agriculture and Forestry. Regions of intensive and less intensive pea cultivation were included. The majority of organic farms studied had converted from conventional to organic cropping in the mid-1990s and had carried out organic cropping on average for seven years.

The number of pea fields examined was 93 in 2002 and 90 in 2003. In both years 32 fields were under organic production. Pea was typically grown in pure stands, but $28 \%$ of fields were mixed stands, predominantly $(87 \%)$ pea with oats. According to EU regulations, the proportion of cereals may not exceed $15 \%$ of the weight of sown seed in a mixture. Altogether 11 pea varieties were grown, of which a Swedish variety Karita (55\%), a Danish variety Stok (19\%) and a Finnish variety Tiina (14\%), were the most common varieties, present in almost $90 \%$ of survey fields.

In most cases there were 1-3 pea fields per farm. The previous crop in pea fields was predominantly spring cereal (Table 1). Grassland had been included in crop rotation during the previous five years in $22 \%$ of conventional fields studied and in $82 \%$ of organic fields. Manure was applied to about $15 \%$ of the fields studied and manure was used both in conventional and organic cropping.

\section{Weed samples}

The occurrence of weeds was assessed from five $1.0 \mathrm{~m}^{2}(1.0 \mathrm{~m} \times 1.0 \mathrm{~m})$ sample quadrats randomly 
Fig. 1. Location of surveyed pea fields in southwestern Finland.

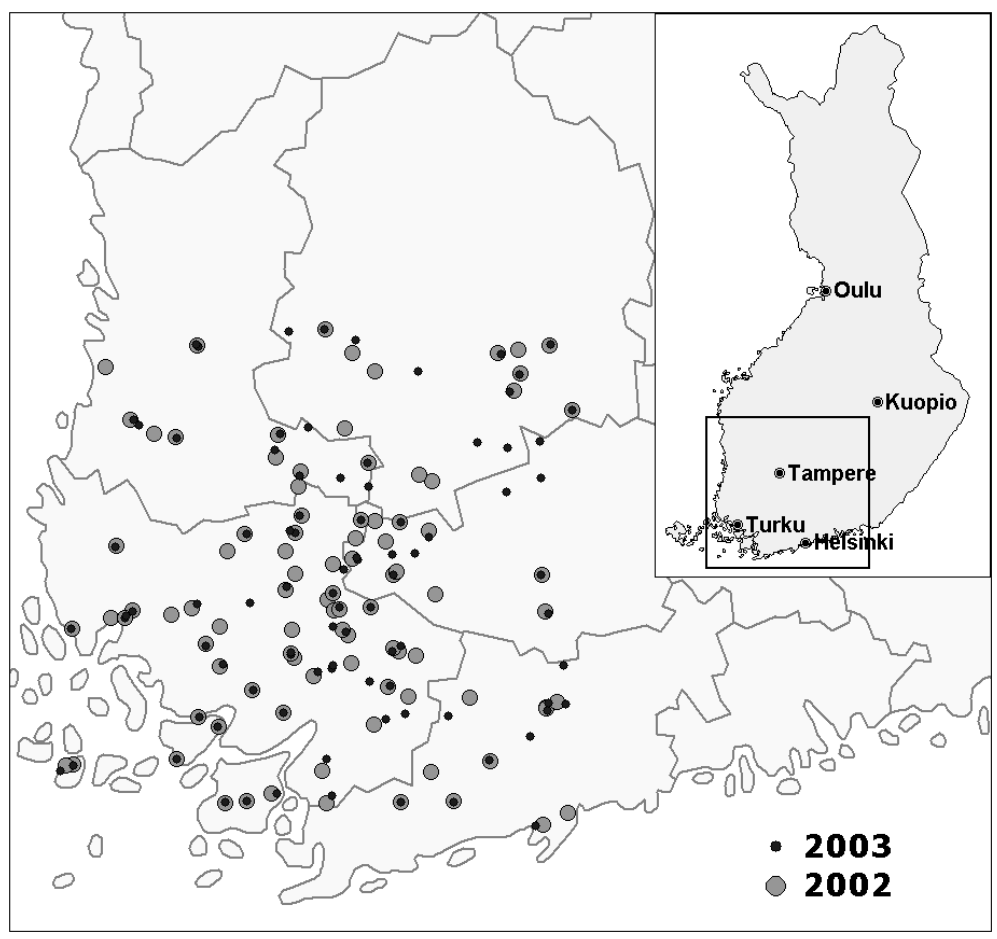

Table 1. Background information on the cropping practices of studied fields. Number of fields (nominal variables) or median, minimum and maximum (continuous variables) of explanatory variables used in Redundancy Analysis (RDA).

\begin{tabular}{|c|c|c|c|c|}
\hline Variable (scale or unit) & Comment & $\begin{array}{l}\text { All data } \\
(\mathrm{n}=171)\end{array}$ & $\begin{array}{l}\text { Conventional } \\
\quad(\mathrm{n}=109)\end{array}$ & $\begin{array}{l}\text { Organic } \\
(\mathrm{n}=57)\end{array}$ \\
\hline Conventional/organic & Farm type & $109 / 62$ & - & - \\
\hline Crop/dairy & Cropping practice & $117 / 54$ & - & - \\
\hline Weed control (yes/no) & $\begin{array}{l}\text { Chemical or mechanical weed } \\
\text { control applied }\end{array}$ & $107 / 64$ & - & - \\
\hline \multicolumn{5}{|l|}{ SPATIAL } \\
\hline Field size (ha) & Size of the field & $3.8(0.1-13)$ & $5(0.5-12)$ & $3(0.1-13.3)$ \\
\hline X co-ordinate & $\begin{array}{l}\mathrm{X} \text { co-ordinate of the field } \\
\text { midpoint }\end{array}$ & $\begin{array}{c}3287738 \\
(3197235- \\
3395928)\end{array}$ & $\begin{array}{c}3285319 \\
(3197235- \\
3395928)\end{array}$ & $\begin{array}{c}3309969 \\
(3211991- \\
3367192)\end{array}$ \\
\hline Y co-ordinate & $\begin{array}{l}\text { Y co-ordinate of the field } \\
\text { midpoint }\end{array}$ & $\begin{array}{c}6737983 \\
(6665859- \\
6830757)\end{array}$ & $\begin{array}{c}6737983 \\
(6665859- \\
6830148)\end{array}$ & $\begin{array}{c}6735754 \\
(6683866- \\
6830757)\end{array}$ \\
\hline \multicolumn{5}{|l|}{ CROP STAND } \\
\hline Age of stand (days) & $\begin{array}{l}\text { Difference between sowing date } \\
\text { and sampling date }\end{array}$ & $52(21-86)$ & $52(23-75)$ & $51(21-86)$ \\
\hline Cover of pea $(\%)$ & $\begin{array}{l}\text { Cover of pea and other crop (data } \\
\text { pooled over five sample quadrats) }\end{array}$ & $260(5-485)$ & $302(48-485)$ & $180(5-440)$ \\
\hline Height of pea (cm) & Height of pea in sample quadrat & $40(4-90)$ & $45(5-90)$ & $25(4-60)$ \\
\hline Mixed (yes/no) & $\begin{array}{l}\text { Pea cropped in the mixture with } \\
\text { other crop }\end{array}$ & $48 / 123$ & $11 / 98$ & $34 / 23$ \\
\hline
\end{tabular}


Salonen, J. et al. Weed flora and weed management of field peas

Table 1. Continued

\begin{tabular}{|c|c|c|c|c|}
\hline Variable (scale or unit) & Comment & $\begin{array}{l}\text { All data } \\
(\mathrm{n}=171)\end{array}$ & $\begin{array}{l}\text { Conventional } \\
\quad(\mathrm{n}=109)\end{array}$ & $\begin{array}{l}\text { Organic } \\
(\mathrm{n}=57)\end{array}$ \\
\hline \multicolumn{5}{|l|}{ WEED CONTROL } \\
\hline No weed control & & - & 9 & - \\
\hline $\begin{array}{l}\text { Herb1: Bentazone or } \\
\text { bentazone+MCPA }\end{array}$ & $\begin{array}{l}\text { Weak effect against POLAV, } \\
\text { VIOAR, POAAN and SENVU }\end{array}$ & - & 34 & - \\
\hline $\begin{array}{l}\text { Herb2: Aclonifen or } \\
\text { Aclonifen+bentazone or } \\
\text { Aclonifen+bentazone+MCPA }\end{array}$ & $\begin{array}{l}\text { Weak effect against VIOAR, } \\
\text { POAAN and SENVU }\end{array}$ & - & 16 & - \\
\hline $\begin{array}{l}\text { Herb3: Metributzin+bentazone or } \\
\text { Metribuzin+bentazone+MCPA or } \\
\text { Metribuzin + aclonifen }\end{array}$ & $\begin{array}{l}\text { Effective against most broad- } \\
\text { leaved species }\end{array}$ & - & 8 & - \\
\hline $\begin{array}{l}\text { Herb4: Metribuzin or } \\
\text { Metribuzin+MCPA }\end{array}$ & Weak effect against GALSP & - & 42 & - \\
\hline $\begin{array}{l}\text { Non-chemical weed control (yes/no) } \\
\text { Years in organic production (years) }\end{array}$ & Mechanical weed control applied & $\begin{array}{l}- \\
-\end{array}$ & $\begin{array}{l}- \\
-\end{array}$ & $\begin{array}{c}5 / 52 \\
7(2-25)\end{array}$ \\
\hline \multicolumn{5}{|l|}{ CROP ROTATION } \\
\hline Spring cereal & & 101 & 71 & 28 \\
\hline Winter cereal & & 26 & 15 & 10 \\
\hline Grassland & & 11 & 1 & 9 \\
\hline Pea & & 12 & 7 & 4 \\
\hline Sugar beet & & 9 & 9 & - \\
\hline Other & & 12 & 6 & 6 \\
\hline Grass (yes/no) & Grassland in crop rotation & $75 / 96$ & $24 / 85$ & $47 / 10$ \\
\hline \multicolumn{5}{|l|}{$\begin{array}{l}\text { SOIL } \\
\text { Soil type }\end{array}$} \\
\hline Coarse & & 14 & 5 & 8 \\
\hline Clay & & 151 & 102 & 45 \\
\hline Organic & & 6 & 2 & 4 \\
\hline $\begin{array}{l}\text { TILLAGE } \\
\text { Autumn ploughing } \\
\text { Spring ploughing } \\
\text { Minimum tillage }\end{array}$ & & $\begin{array}{c}121 \\
15 \\
35\end{array}$ & $\begin{array}{c}81 \\
6 \\
22\end{array}$ & $\begin{array}{c}40 \\
8 \\
9\end{array}$ \\
\hline \multicolumn{5}{|l|}{ FERTILIZATION } \\
\hline Manure (yes/no) & Manure applied as fertilizer & $25 / 146$ & $13 / 96$ & $12 / 45$ \\
\hline $\mathrm{N}\left(\mathrm{kg} \mathrm{ha}^{-1}\right)$ & $\begin{array}{l}\text { Amount of nitrogen in mineral } \\
\text { fertilization and manure }\end{array}$ & $32(0-100)$ & $44(0-100)$ & $0(0-39)$ \\
\hline $\mathrm{P}\left(\mathrm{kg} \mathrm{ha}^{-1}\right)$ & $\begin{array}{l}\text { Amount of phosphorus in mineral } \\
\text { fertilization and manure }\end{array}$ & $6(0-42)$ & $11(0-28)$ & $0(0-32)$ \\
\hline
\end{tabular}

located in each field. The term frequency refers to the proportion of fields where the species was found in quadrats. In addition, visible patches of the common and troublesome perennial weeds Cirsium arvense, Elymus repens and Sonchus ar- vensis were recorded separately over the whole field. Weed cover was visually assessed and recorded using a scale of $0-3(0=$ not present, $1=$ less than $5 \%$ cover, $2=5-25 \%$ cover and $3=$ more than $25 \%$ cover) by species. The weed cover data 
Vol. 14 (2005): 189-201.

from five sample quadrats were pooled and the sum was used as a measure of weed abundance in the data analyses. The plant species nomenclature follows that of Hämet-Ahti et al. (1998). The full scientific names with attribution are given in Table 2. Bayer codes for weed species (Bayer 1992) are used in the presentation of results.

\section{Statistical analyses}

Conventional and organic production are characterised by different crop management practices, including fertiliser application method and amount. Herbicide application in conventional cropping clearly creates a significant selection pressure in weed communities (Hald 1999, Hyvönen and Salonen 2002, Poggio et al. 2004) that is absent in organic cropping. Several factors associated with crop rotation, crop management and diverse environmental variables, should be taken into account (see e.g. Haas and Streibig 1982, Rydberg and Milberg 2000). Therefore, the application of multivariate methods was considered appropriate for analysing these complex data (see e.g. Salonen 1993, Hallgren et al. 1999, Lepŝ and Šmilauer 2003).

The complete data set derived from 183 fields that were used in frequency calculations (Table 2). In the ordination analyses some fields were excluded due to missing data of explanatory variables (see Table 1 for the number of fields in each analysis). Data on factors involved in each field were collected through observation, measurement or by interviewing the farmer. The statistical analyses were performed either using SAS procedures (version 8.2., SAS Institute Inc. 1999) or with CANOCO 4 software (ter Braak and Šmilauer 1998).

The preliminary analysis of the data was conducted using Detrended Correspondence Analysis (DCA) to measure the lengths of gradients. Since the lengths of gradients for the first and the second DCA axes were short (2.4 and 2.5, respectively), an analysis with the linear response model (i.e. Redundancy Analysis, RDA) was considered more appropriate than analysis with the unimodal re- sponse model (i.e. Canonical Correspondence Analysis, CCA) (see Lepŝ and Šmilauer 2003). The default options of CANOCO were applied. All the species for which there was a single observation (13 species in all data, 15 species in organically cropped fields and 18 in conventionally cropped fields) were given a zero weight in the analyses (i.e. they did not affect the analyses).

In the first series of analyses of complete data, all explanatory variables (see Table 3) were included in the forward selection procedure of CANOCO. The statistical significance of the terms was tested using the unrestricted Monte Carlo permutation test (999 permutations). Explanatory variables with a $\mathrm{P}$-value $>0.05$ were excluded from further analyses (Table 3). For the exploration of general patterns in species composition of the weed community, and the relationship between the species composition and explanatory variables, RDA was conducted on the species matrix constrained by statistically significant explanatory variables (Fig. 2). The significance of the first RDA axes and the overall significance of the RDA models were evaluated using Monte Carlo permutation tests with trace as a test statistic and 999 permutations.

In the second series of analyses, weed communities of conventionally and organically cropped fields were analysed separately (data on 109 and 57 fields, respectively). The relative importance of various factors was studied using variation partitioning (Borcard et al. 1992). For variation partitioning, the explanatory variables were classified into seven groups (Table 1). The variables included in the groups of weed control and fertilization differed between cropping practices (see Table 3 ). All groups of explanatory variables were submitted to the forward-selection procedure, and the following series of analyses were conducted with statistically significant explanatory variables: 1) RDA of the species matrix constrained by the matrix of each group of significant explanatory variables one at a time and 2) partial RDA of the species matrix constrained by the matrix of each group of significant explanatory variables one at a time and using one of the other matrices as a covariate. Variation partitioning was conducted by applying 
Salonen, J. et al. Weed flora and weed management of field peas

the variation explained by the explanatory variables, i.e., the sum of all canonical eigenvalues in RDA analysis where all significant explanatory variables and no covariables were included in the analysis, as a measure of the total variation ( $\varnothing \mathrm{k}$ land and Eilertsen 1994, Økland 1999).

\section{Results}

\section{Weed species composition and weed cover}

A total of 76 weed species were recorded in sample quadrats. The 29 most frequent weed species were found in more than $10 \%$ of surveyed fields (Table 2). The average number of weed species per field was $10(\min 3, \max 21)$ under conventional cropping and 18 ( $\min 8, \max 31)$ under organic cropping.

The most frequent weed species in both cropping systems were Chenopodium album, Stellaria media and Viola arvensis (Table 2). Of the total 76 recorded weed species 59 species occurred in conventionally cropped fields and 68 species in organically cropped fields. There were 17 weed species that were found only in organically cropped fields (e.g. Achillea millefolium L., Barbarea vulgaris R.Br., Rumex longifolius DC. and Sonchus asper (L.) Hill). On the other hand, 8 weed species (e.g. Atriplex patula L., Avena fatua L., Solanum nigrum L.) were found occasionally in some conventionally cropped fields. In some fields volunteer crop plants including Avena sativa L., Hordeum vulgare L., Linum usitatissimum L. and Phleum pratense $\mathrm{L}$. occurred as weeds.

To supplement information on the most common perennial weed species in our random sample quadrats, comprehensive observation of weed patches increased the number of fields infested with Cirsium arvense (frequency $33 \%$ vs. $43 \%$ ). This suggested that growth of $C$. arvense was more patchy, or the patches were higher and more visible than those of Elymus repens and Sonchus ar- vensis in early July. In all, these three perennial species were more frequently found in organic fields than in conventional fields (Table 2).

The observed weed cover of individual species was usually less than $5 \%$, corresponding to the rank value 1 on the scale for visual observation. The crop cover, pea alone or pea with cereal, was on average $60 \%$ under conventional cropping and $40 \%$ under organic cropping in early July. On some organic farms pea stands completely failed following poor crop emergence and/or vigorous weed growth.

In the analysis of the comprehensive data (all 171 fields) using RDA, only eight variables proved to be statistically significant in the forward selection procedure (Table 3 ). The first RDA axis captured $13.5 \%$ of the variation in the species composition and $67.1 \%$ of the variation in the speciesenvironment relation; the second RDA axes captured only a minor portion of the variation (2.2 and $11.1 \%$, respectively). A Monte Carlo permutation test showed both the first and all RDA axes together to be statistically significant $(\mathrm{P}<0.01)$.

The main gradient in the variation in species composition along the first ordination axis was the difference between conventionally and organically cropped fields (Fig. 2). In addition to cropping practices, the first axis was related to weed control and grassland-dominated crop rotations. The most dominant species included herbicide-susceptible Spergula arvensis and Erysimum cheiranthoides as well as species typical of grassland-dominated crop rotations, e.g. Elymus repens, Ranunculus repens and Plantago major. The second axis was related to properties of the crop stand (cover and age) as well as soil type and tillage. The most dominant species included herbicide tolerant Galium spurium and Fumaria officinalis.

\section{Cropping practices}

Chemical weed control was practised on $92 \%$ of conventionally cropped fields. Bentazone and metribuzin were the most frequently applied active ingredients. Other compounds applied were aclonifen or MCPA mixed with bentazone. In addition 
Vol. 14 (2005): 189-201.

Table 2. Frequencies of occurrence (\%) of 32 most frequent weed species in pea fields.

\begin{tabular}{|c|c|c|c|c|c|c|}
\hline \multirow[t]{3}{*}{ Species/Taxon } & \multirow[t]{3}{*}{ Bayer code } & \multicolumn{4}{|c|}{ Production type } & \multirow[t]{3}{*}{ Total } \\
\hline & & \multicolumn{3}{|c|}{ Conventional } & \multirow[t]{2}{*}{ Organic } & \\
\hline & & Unsprayed & Sprayed & All & & \\
\hline Achillea millefolium $\mathrm{L}$. & ACHMI & 0 & 0 & 0 & $8^{*}$ & 3 \\
\hline Brassica rapa L. ssp. oleifera (DC.) METZG. & BRSRO & 22 & 10 & 11 & $25^{*}$ & 16 \\
\hline Capsella bursa-pastoris (L.) MEDIK. & CAPBP & 22 & 17 & 18 & $47^{*}$ & 28 \\
\hline Chenopodium album $\mathrm{L}$. & CHEAL & 89 & 68 & 70 & $97^{*}$ & 79 \\
\hline Cirsium arvense (L.) SCOP. & CIRAR & 22 & 21 & 21 & $56^{*}$ & 33 \\
\hline Elymus repens $(\mathrm{L}$.$) GOULD$ & AGRRE & 67 & 56 & 57 & $75^{*}$ & 63 \\
\hline Equisetum arvense $\mathrm{L}$. & EQUAR & 22 & 12 & 13 & 22 & 16 \\
\hline Erysimum cheiranthoides $\mathrm{L}$. & ERYCH & 78 & 38 & 41 & $81^{*}$ & 55 \\
\hline Fallopia convolvulus (L.) À.LÖVE & POLCO & 44 & 55 & 55 & $75^{*}$ & 62 \\
\hline Fumaria officinalis L. & FUMOF & 67 & 55 & 56 & 72 & 62 \\
\hline Galeopsis L. spp. & GAESS & 78 & 55 & 57 & $97^{*}$ & 71 \\
\hline Galium spurium L. a & GALSP & 33 & 65 & 63 & 59 & 62 \\
\hline Gnaphalium uliginosum $\mathrm{L}$. & GNAUL & 11 & 2 & 3 & $13^{*}$ & 6 \\
\hline Lamium L. spp. & LAMSS & 11 & 43 & 40 & $56^{*}$ & 46 \\
\hline Lapsana communis $\mathrm{L}$. & LAPCO & 56 & 40 & 41 & $70^{*}$ & 51 \\
\hline Matricaria matricarioides (LESS.) PORT. & MATMT & 11 & 10 & 10 & $30^{*}$ & 17 \\
\hline Myosotis arvensis (L.) HILL & MYOAR & 56 & 16 & 19 & $47^{*}$ & 32 \\
\hline Persicaria lapathifolia (L.) GRAY & POLLA & 33 & 12 & 13 & $59^{*}$ & 30 \\
\hline Plantago major L. & PLAMA & 11 & 7 & 8 & $20^{*}$ & 12 \\
\hline Pоа аппиа $\mathrm{L}$. & POAAN & 22 & 12 & 13 & 17 & 14 \\
\hline Polygonum aviculare $\mathrm{L}$. & POLAV & 44 & 44 & 44 & 47 & 45 \\
\hline Ranunculus repens $\mathrm{L}$. & RANRE & 11 & 4 & 4 & $22^{*}$ & 10 \\
\hline Sonchus arvensis L. & SONAR & 67 & 44 & 45 & $80^{*}$ & 57 \\
\hline Spergula arvensis $\mathrm{L}$. & SPRAR & 56 & 15 & 18 & $70^{*}$ & 36 \\
\hline Stellaria media (L.) VILL. & STEME & 67 & 68 & 68 & $92^{*}$ & 77 \\
\hline Taraxacum officinale WEBER in WIGGERS & TAROF & 0 & 11 & 10 & 17 & 13 \\
\hline Thlaspi arvense $\mathrm{L}$. & THLAR & 22 & 12 & 13 & $47^{*}$ & 25 \\
\hline Trifolium L. spp. & TRFSS & 67 & 21 & 24 & $63^{*}$ & 38 \\
\hline Tripleurospermum inodorum (L.) SCH.BIP. & MATIN & 33 & 40 & 39 & $73^{*}$ & 51 \\
\hline Tussilago farfara $\mathrm{L}$. & TUSFA & 0 & 3 & 3 & $16^{*}$ & 7 \\
\hline Vicia cracca $\mathrm{L}$. & VICCR & 11 & 7 & 8 & $27^{*}$ & 14 \\
\hline Viola arvensis MURRAY ${ }^{\mathrm{b}}$ & VIOAR & 100 & 79 & 81 & 81 & 81 \\
\hline Number of fields & & 9 & 110 & 119 & 64 & 183 \\
\hline
\end{tabular}

${ }^{\mathrm{a}}=$ incl. G. aparine ${ }^{\mathrm{b}}=$ incl. V. tricolor

* Significant difference in frequencies between "Conventional All" and "Organic" (Fisher's Exact Test, $\mathrm{P}<0.05$ )

to the relatively effective control of broad-leaved weeds, grass weeds, Elymus repens in particular, were controlled separately with selective graminicides, including fluazifop-P-butyl, propaquizafop and quizalofop-P-ethyl. However, selective grass weed control was not a common practice and was carried out only on seven of 119 conventionally cropped fields. In organically cropped fields, me- chanical weed control, namely harrowing, was carried out only in five fields (i.e. 9\%). More than $80 \%$ of survey fields were ploughed, mainly in autumn, but in some cases in the spring.

In conventionally cropped fields, the RDA analysis showed that the characteristics of crop stand - the height of pea, the age of crop stand and the mixed crop stand - were the most important 
Salonen, J. et al. Weed flora and weed management of field peas

Table 3. Explanatory variables included in the forward selection procedure of Redundancy Analysis (RDA), their conditional variances and statistical significance. Statistical significance of variables was determined by forward selection in RDA with the unrestricted Monte Carlo $(n=999)$ permutation test.

\begin{tabular}{|c|c|c|c|c|c|c|c|}
\hline \multirow[t]{2}{*}{ Variable } & \multirow[t]{2}{*}{ Code } & \multicolumn{2}{|c|}{ All data } & \multicolumn{2}{|c|}{ Conventional } & \multicolumn{2}{|c|}{ Organic } \\
\hline & & $\begin{array}{c}\text { Conditional } \\
\text { variance }^{1}\end{array}$ & P-value & $\begin{array}{c}\text { Conditional } \\
\text { variance }^{1}\end{array}$ & P-value & $\begin{array}{c}\text { Conditional } \\
\text { variance }^{1}\end{array}$ & P-value \\
\hline Conventional/organi & cORGANIC & 0.12 & $0.001 *$ & - & - & - & - \\
\hline Crop/dairy & CROP & 0.01 & 0.101 & - & - & - & - \\
\hline Weed control & WCTRL & 0.02 & $0.001 *$ & - & - & - & - \\
\hline $\begin{array}{l}\text { SPATIAL } \\
\text { Field size } \\
\text { X co-ordinate } \\
\text { Y co-ordinate }\end{array}$ & $\begin{array}{l}\text { AREA } \\
\mathrm{X} \\
\mathrm{Y}\end{array}$ & $\begin{array}{l}0 \\
0.01 \\
0.01\end{array}$ & $\begin{array}{l}0.424 \\
0.086 \\
0.048 *\end{array}$ & $\begin{array}{l}0.01 \\
0.01 \\
0.02\end{array}$ & $\begin{array}{l}0.539 \\
0.122 \\
0.040 *\end{array}$ & $\begin{array}{l}0.02 \\
0.03 \\
0.03\end{array}$ & $\begin{array}{l}0.154 \\
0.185 \\
0.020 *\end{array}$ \\
\hline $\begin{array}{l}\text { CROP STAND } \\
\text { Age of stand } \\
\text { Cover of pea } \\
\text { Height of pea } \\
\text { Mixed/Non-mixed }\end{array}$ & $\begin{array}{l}\text { AGE } \\
\text { COVER } \\
\text { HEIGHT } \\
\text { MIXED }\end{array}$ & $\begin{array}{l}0.01 \\
0.01 \\
0.01 \\
0\end{array}$ & $\begin{array}{l}0.001^{*} \\
0.003^{*} \\
0.205 \\
0.329\end{array}$ & $\begin{array}{l}0.03 \\
0.01 \\
0.03 \\
0.02\end{array}$ & $\begin{array}{l}0.002 * \\
0.241 \\
0.001 * \\
0.022^{*}\end{array}$ & $\begin{array}{l}0.03 \\
0.02 \\
0.02 \\
0.02\end{array}$ & $\begin{array}{l}0.036^{*} \\
0.140 \\
0.516 \\
0.442\end{array}$ \\
\hline $\begin{array}{l}\text { WEED CONTROL } \\
\text { Chemical } \\
\text { None } \\
\text { Herb1 } \\
\text { Herb2 } \\
\text { Herb3 } \\
\text { Herb4 }\end{array}$ & $\begin{array}{l}\text { NHERB } \\
\text { HERB1 } \\
\text { HERB2 } \\
\text { HERB3 } \\
\text { HERB4 }\end{array}$ & $\begin{array}{l}- \\
- \\
- \\
- \\
-\end{array}$ & $\begin{array}{l}- \\
- \\
- \\
- \\
-\end{array}$ & $\begin{array}{l}0.02 \\
0.04 \\
0.02 \\
0.02 \\
0.03\end{array}$ & $\begin{array}{l}0.003 * \\
0.001 * \\
0.135 \\
- \\
0.008 *\end{array}$ & $\begin{array}{l}- \\
- \\
- \\
- \\
-\end{array}$ & $\begin{array}{l}- \\
- \\
- \\
- \\
-\end{array}$ \\
\hline $\begin{array}{l}\text { Non-chemical } \\
\text { Years in organic } \\
\text { production }\end{array}$ & $\begin{array}{l}\text { NONCHE } \\
\text { OYEARS }\end{array}$ & $\begin{array}{l}- \\
-\end{array}$ & $\begin{array}{l}- \\
-\end{array}$ & $\begin{array}{l}- \\
-\end{array}$ & $\begin{array}{l}- \\
-\end{array}$ & $\begin{array}{l}0.01 \\
0.02\end{array}$ & $\begin{array}{l}0.794 \\
0.625\end{array}$ \\
\hline $\begin{array}{l}\text { CROP ROTATION } \\
\text { Pre crop } \\
\text { Spring cereal } \\
\text { Winter cereal } \\
\text { Grassland } \\
\text { Pea } \\
\text { Sugar beet } \\
\text { Other }\end{array}$ & $\begin{array}{l}\text { SPRINGC } \\
\text { WINTERC } \\
\text { GRASS } \\
\text { PEA } \\
\text { SUGAR } \\
\text { OCROP }\end{array}$ & $\begin{array}{l}0 \\
0 \\
0.01 \\
+ \\
0 \\
0.01\end{array}$ & $\begin{array}{l}0.736 \\
0.271 \\
0.760 \\
\dagger \\
0.111 \\
0.347\end{array}$ & $\begin{array}{r}0.01 \\
<0.01 \\
0.02 \\
0.01 \\
<0.01 \\
0.01\end{array}$ & $\begin{array}{l}0.417 \\
0.732 \\
0.085 \\
0.286 \\
+ \\
0.400\end{array}$ & $\begin{array}{l}0.02 \\
0.01 \\
0.01 \\
0.01 \\
\dagger \\
0.03\end{array}$ & $\begin{array}{l}0.114 \\
0.955 \\
0.613 \\
\dagger \\
\dagger \\
0.258\end{array}$ \\
\hline Grass/No grass & GROT & 0.01 & $0.014 *$ & 0.02 & $0.009 *$ & 0.01 & 0.723 \\
\hline $\begin{array}{l}\text { SOIL } \\
\text { Soil type } \\
\text { Coarse } \\
\text { Clay } \\
\text { Organic }\end{array}$ & $\begin{array}{l}\text { COARSE } \\
\text { CLAY } \\
\text { ORG }\end{array}$ & $\begin{array}{c}0.01 \\
0.02 \\
\dagger\end{array}$ & $\begin{array}{l}0.073 \\
0.001 * \\
\dagger\end{array}$ & $\begin{array}{l}0.01 \\
0.01 \\
0.01\end{array}$ & $\begin{array}{c}0.192 \\
0.391 \\
\dagger\end{array}$ & $\begin{array}{l}0.02 \\
0.03 \\
0.03\end{array}$ & $\begin{array}{l}0.201 \\
0.055 \\
0.072\end{array}$ \\
\hline $\begin{array}{l}\text { TILLAGE } \\
\text { Autumn ploughing } \\
\text { Spring ploughing } \\
\text { Minimum tillage }\end{array}$ & $\begin{array}{l}\text { APLOUGH } \\
\text { SPLOUGH } \\
\text { MTILLAGE }\end{array}$ & $\begin{array}{l}0.01 \\
0.01 \\
0.01\end{array}$ & $\begin{array}{c}0.116 \\
\dagger \\
0.028 *\end{array}$ & $\begin{array}{l}0.01 \\
0.01 \\
0.01\end{array}$ & $\begin{array}{c}0.344 \\
\dagger \\
0.076\end{array}$ & $\begin{array}{l}0.02 \\
0.02 \\
0.02\end{array}$ & $\begin{array}{l}0.354 \\
0.161 \\
+\end{array}$ \\
\hline $\begin{array}{l}\text { FERTILIZATION } \\
\text { Manure } \\
\mathrm{N} \\
\mathrm{P}\end{array}$ & $\begin{array}{l}\text { MANURE } \\
\mathrm{N} \\
\mathrm{P}\end{array}$ & $\begin{array}{l}0 \\
0.01 \\
0.01\end{array}$ & $\begin{array}{l}0.818 \\
0.905 \\
0.430\end{array}$ & $\begin{array}{r}<0.01 \\
0.01 \\
0.01\end{array}$ & $\begin{array}{l}0.936 \\
0.538 \\
0.509\end{array}$ & $\begin{array}{c}0.02 \\
- \\
-\end{array}$ & $\begin{array}{l}0.651 \\
- \\
-\end{array}$ \\
\hline
\end{tabular}

${ }^{1}$ The share of variance explained by each variable at the time it was included in the model.

*Included in the further analyses.

$\dagger$ No value received in the RDA analysis. 
Vol. 14 (2005): 189-201.

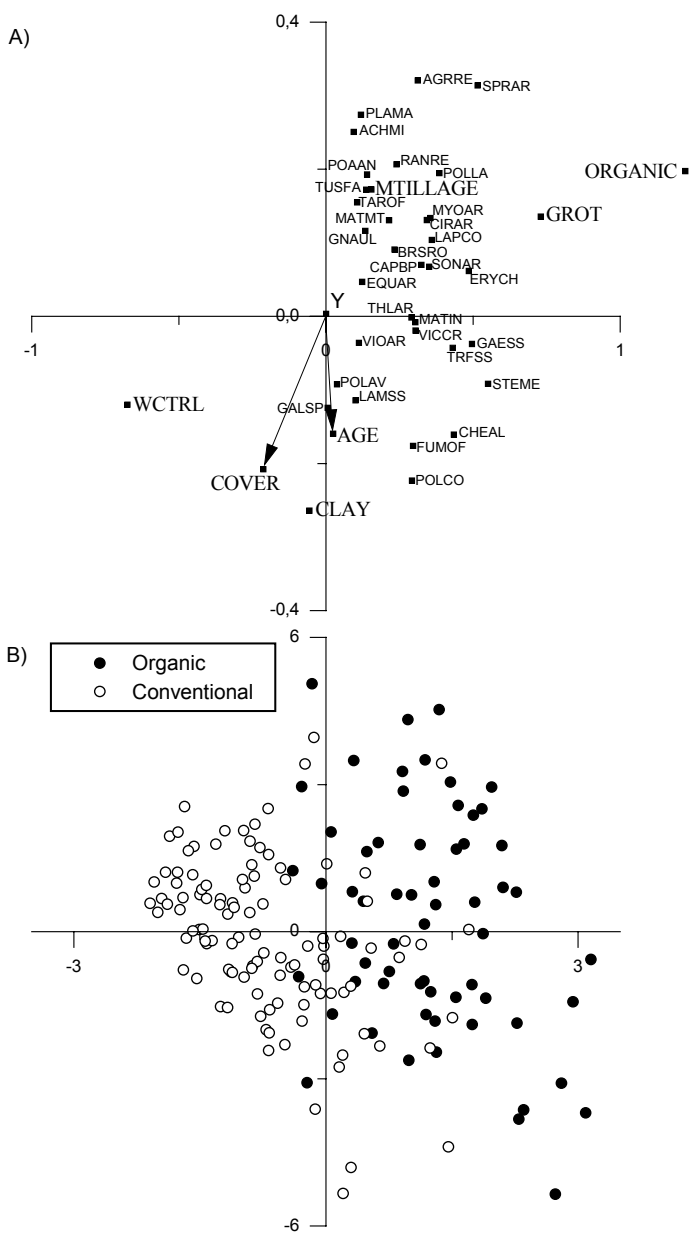

Fig. 2. Redundancy Analysis (RDA) of weed species and all statistically significant explanatory variables. Plot of species (only 32 most frequent species are shown) and explanatory variables (A) and of fields (B). Eigenvalues for axes 1 and 2 are 0.135 and 0.022 , respectively. See Table 3 for abbreviations of explanatory variables and Table 2 for abbreviations of species' names.

factors (with $38.7 \%$ share) explaining variation in the species composition (Table 4). In general, conventional pea stands were higher and denser than those of organic pea (Table 1). Application of herbicides was the second most important group of factors explaining variation (with $37.6 \%$ share) in species composition. Within the weed control group, the application of bentazone alone or bentazone with MCPA, and application of pure metribuzin or metribuzin with MCPA, were the most important explanatory variables.

In the RDA analysis of organic fields, the two significant variables - y co-ordinate and age of crop stand - explained almost equal shares of the variation, $51.7 \%$ and $48.3 \%$, respectively. The variables for weed management were not statisti-

Table 4. Partitioning of variation among the groups of variables for conventionally cropped fields.

\begin{tabular}{|c|c|c|c|c|c|}
\hline \multirow[b]{2}{*}{ Variable X } & \multirow[b]{2}{*}{ Covariable Y } & \multicolumn{3}{|c|}{ Variation explained (\%) by } & \multirow[b]{2}{*}{ Other } \\
\hline & & Variable X & Joint of $\mathrm{X}$ and $\mathrm{Y}$ & Covariable $\mathrm{Y}$ & \\
\hline \multirow[t]{4}{*}{ Weed control } & All variables & 37.6 & 7.6 & 54.8 & 0 \\
\hline & Crop stand & 41.4 & 3.8 & 40.3 & 14.5 \\
\hline & Crop rotation & 43.0 & 2.2 & 9.7 & 45.1 \\
\hline & Spatial & 42.5 & 2.7 & 6.5 & 48.3 \\
\hline \multirow[t]{3}{*}{ Crop stand } & All variables & 38.7 & 5.4 & 55.9 & 0 \\
\hline & Crop rotation & 41.9 & 2.1 & 9.7 & 46.3 \\
\hline & Spatial & 44.6 & -0.5 & 9.7 & 46.2 \\
\hline \multirow[t]{2}{*}{ Crop rotation } & All variables & 8.1 & 3.7 & 88.2 & 0 \\
\hline & Spatial & 10.8 & 1.1 & 8.1 & 80 \\
\hline Spatial & All variables & 5.9 & 3.2 & 90.9 & 0 \\
\hline
\end{tabular}


Salonen, J. et al. Weed flora and weed management of field peas

cally significant in the forward selection procedure (Table 3).

\section{Discussion}

The total number of weed species (76) recorded in pea fields illustrates the species richness of arable fields. It was, however, lower than the number of species (188) recorded in a survey of spring cereals (Salonen et al. 2001a). An obvious reason for this is that a smaller number of fields were surveyed in a more restricted geographical area. Consequently, our data set consisted mainly of samples from clay soils, which are predominant in southwestern Finland. In comparison with earlier studies in organically cultivated cereals fields, in the mid-1980s Mela (1988) found 103 weed species or taxa (221 fields studied) and Salonen et al. (2001b) in the late 1990s found 126 species or taxa (165 fields studied). In all surveys the most frequently occurring species were the same, but they ranked slightly differently. Similarities in weed flora of pea fields were recorded at the European level (Uludag et al. 2003).

The composition of weed flora is a result of long-term cropping histories, management practices and environmental conditions (see e.g. Håkansson 2003). As a consequence of such selection pressure within weed flora Chenopodium album, Galeopsis spp. and Stellaria media are characteristic of cereal-dominated rotations in Finland and have been among the most common species in all weed surveys of spring cereals (Mukula et al. 1969, Erviö and Salonen 1987, Mela 1988, Salonen et al. 2001a) as well as e.g. in organic spring cereals in Sweden (Rydberg and Milberg 2000). Clearly, the same weed species emerging from an established seed bank dominated our survey fields where pea was a component of cereal-based crop sequences. Moreover, the three mentioned species seem to be particularly typical of organic pea production as they exceeded the frequency level of $90 \%$.

As expected, most variation in the species composition was established between organic and conventional cropping practices. The difference between cropping measures was related to weed control and the inclusion of grassland in the crop rotation. Both of these factors were also important in the separate analysis of conventionally cropped fields. The importance of weed control was not surprising since application of herbicides was shown to be an important factor previously (Hald 1999, Hyvönen and Salonen 2002, Hyvönen et al. 2003). In contrast, the effect of crop rotation has often been shown to be weak (Bàrberi et al. 1997, Andersson and Milberg 1998, Doucet et al. 1999), unless grasslands are included in the rotation (Paatela and Erviö 1971, Sjursen 2001). Evidently, organically cropped fields had more diverse crop rotation histories than conventionally cropped fields. The inclusion of grassland in a crop rotation increased the abundance of some perennial species (e.g. Ranunculus repens and Achillea millefolium) that are adapted to grasslands (Raatikainen and Raatikainen 1975).

In both cropping practices, the characteristics of crop stand explained a large share of the variation in the species composition. Age of crop stand, i.e. the difference between sowing and sampling dates, was an important variable among the crop stand characteristics. Apparently, competitive ability of crop stand is an important factor for reducing weed problems, especially under organic cropping where application of herbicides is avoided (Bond and Lennartson 1999). Pea breeding programmes in Finland have been successful in increasing the protein content of peas and developing high-yielding semileafless afila-type varieties (Hovinen 1988). However, such varieties are poor competitors against weeds. Competitive ability of pea stands should be taken into account when breeding new cultivars. Meanwhile, effective direct weed control is a prerequisite for a high pea yield.

Lawson (1983) showed that even though highdensity pea stands suppress weeds very effectively, densely sown pea is no less vulnerable to yield loss than those at lower density are. In Finland the recommended crop density for semileafless pea is 110-120 plants $\mathrm{m}^{-2}$ (Laine and Kontturi 2002). The plant density was not recorded in our survey fields but the cover assessments indicate that in many 
Vol. 14 (2005): 189-201.

cases the crop stand was not dense enough to compete against the weeds effectively. Intercropping of pea with cereals would evidently improve weed growth suppression (Hauggaard-Nielsen et al. 2001, Poggio 2005).

Weed management did not explain the variation in the species composition in organically cropped fields. Organic crop production aims at maintenance of weeds at a manageable level by cultural means (Bond and Lennartsson 1999). Weed management strategies should include diverse applications of crop rotation, cultivations, crop density, cultivar selection and mechanical control (Stopes and Millington 1991). Unfortunately, only a few of the survey farms carried out mechanical weed control even though it might have provided at least moderate control at an acceptable risk of crop damage (Larsen and Andreasen 2004). Organic farming appears to be beneficial for biodiversity since the number of weed species is often higher than in conventional farming (e.g. Hald 1999, Salonen et al. 2001a). This is in agreement with our results from pea fields.

The efficacy of chemical control was relatively good in most of the survey fields. For conventional cropping, the selection of herbicides available seems to be satisfactory for adequate weed control, but control costs are high. Mixtures of different active ingredients were commonly applied to broaden the control spectrum since e.g. Galium spurium was clearly a problem weed that remained in fields treated with metribuzin alone. Likewise, Fallopia convolvulus, Polygonum aviculare or Viola arvensis were not properly controlled with some other herbicides applied alone. However, even sensitive species like Chenopodium album and Stellaria media having a long period of emergence (Erviö 1981) were frequent in conventional fields, although much less abundant than in organic fields.

The cost of herbicides applied at the recommended rates varied between $€ 29-95$ ha $^{-1}$ in Finland in 2004. In Finnish field experiments the yield increase achieved with chemical weed control has reached $500 \mathrm{~kg} \mathrm{ha}^{-1}$ (Pessala and Erviö 1979, Ruuttunen 1999). However, as mentioned by Knott (1994), it is questionable to recommend chemical weed control as being always economic at the cur- rent price level of food peas, $€ 200-250$ per 1000 $\mathrm{kg}$ (Ministry of Agriculture and Forestry 2004). Nevertheless, herbicide use is advisable as it represents a long-term strategy to keep the weed pressure at a low level.

In conclusion, the weed flora of pea fields was similar to that recorded in earlier surveys of spring cereal fields. Weeds can be efficiently managed with herbicides under conventional cropping but represent a great problem under organic cropping in which implementation of mechanical weed control methods is advisable in order to reduce yield losses. Mixed cultivation of pea with cereals is recommended, particularly under organic cropping, as it favours crop competition against weeds.

Weeds can not be regarded as a particular disincentive to planned expansion in pea production although they are expensive to control under conventional cropping and challenging to manage under organic cropping.

Acknowledgements. The weed survey was part of the research programme "Pea as a source of domestic protein", coordinated by Professor Pirjo Peltonen-Sainio. We thank farmers who allowed us to visit their fields and provided us with information about farming practices. The authors acknowledge the efforts of Dr. Erja Huusela-Veistola in the arrangement of farm visits and preparatory steps of data handling. Both Erja and Mr. Pentti Ruuttunen gave valuable comments on the manuscript. The survey was financed by MTT Agrifood Research Finland and the Ministry of Agriculture and Forestry.

\section{References}

Andersson, T.N. \& Milberg, P. 1998. Weed flora and the relative importance of site, crop, crop rotation, and nitrogen. Weed Science 46: 30-38.

Bàrberi, P., Silvestri, N. \& Bonari, E. 1997. Weed communities of winter wheat as influenced by input level and rotation. Weed Research 37: 301-313.

Bayer 1992. Important crops of the world and their weeds. 2nd ed. Bayer AG, Leverkusen. $1682 \mathrm{p}$.

Bond, W. \& Lennartsson, M.E.K. 1999. Organic weed control - back to the future. In: Proceedings 1999 Brighton crop protection conference - weeds. The British Crop Protection Council. p. 929-938. 


\section{Salonen, J. et al. Weed flora and weed management of field peas}

Borcard, D., Legendre, P. \& Drapeau, P. 1992. Partialling out the spatial component of ecological variation. Ecology 73: 1045-1055.

Doucet, C., Weaver, S.E., Hamill, A.S. \& Zhang, J. 1999. Separating the effects of crop rotation from weed management on weed density and diversity. Weed Science 47: 729-735.

Ervio, L.-R. 1981. The emergence of weeds in the field. Annales Agriculturae Fenniae 20: 292-303.

Erviö, L.-R. \& Salonen, J. 1987. Changes in the weed population of spring cereals in Finland. Annales Agriculturae Fenniae 26: 210-226.

Haas, H. \& Streibig, J.C. 1982. Changing patterns of weed distribution as a result of herbicide use and other agronomic factors. In: LeBaron, H.M. \& Gressel, J. (eds.). Herbicide resistance in plants. J. Wiley \& Sons. p. 5779.

Håkansson, S. 2003. Weeds and weed management on arable land: an ecological approach. CABI Publishing, UK. 274 p.

Hald, A.B. 1999. Weed vegetation (wild flora) of long established organic versus conventional cereal fields in Denmark. Annals of Applied Biology 14: 307-314.

Hallgren, E., Palmer, M.W. \& Milberg, P. 1999. Data diving with crossvalidation: an investigation of broad-scale gradients in Swedish weed communities. Journal of Ecology 87: 1037-1051.

Hämet-Ahti, L., Suominen, J., Ulvinen, T. \& Uotila, P. (eds.). 1998. Retkeilykasvio (Field Flora of Finland), 4. ed. Finnish Museum of Natural History, Botanical Museum. Helsinki. 656 p.

Hauggaard-Nielsen, H., Ambus, P. \& Jensen, E.S. 2001. Interspecific competition, $\mathrm{N}$ use and interference with weeds in pea-barley intercropping. Field Crops Research 70: 101-109.

Hovinen, S. 1988. Breeding of a protein pea ideotype for Finnish conditions. Journal of Agricultural Science in Finland 60:1-72.

Hyvönen, T., Ketoja, E., Salonen, J., Jalli, H. \& Tiainen, J. 2003. Weed species diversity and community composition in organic and conventional cropping of spring cereals. Agriculture, Ecosystems \& Environment 97: 131-149.

Hyvönen, T. \& Salonen, J. 2002. Weed species diversity and community composition in cropping practices at two intensity levels - a six-year experiment. Plant Ecology 159: 73-81.

Knott, C.T. 1994. Weed control for peas and beans at world market prices In: Clarke, J. et al. (eds.). Arable farming under CAP reform, 12-14 December, Cambridge, UK. Aspects of Applied Biology 40, 2: 351-360. ISBN 02651491

Laine, A. \& Kontturi, M. 2002. Herne. In: Kangas, A. \& Teräväinen, H. (eds.). Peltokasvilajikkeet 2002. Tieto tuottamaan 96. p. 48-51.

Larsen, H.L.F. \& Andreasen, C. 2004. The sensitivity of field peas (Pisum sativum L.) to weed harrowing. In: Proceedings of the 6th EWRS Workshop on Physical and Cultural Weed Control, Lillehammer, Norway. p. 55-57. Updated 22 Dec 2004. Available on the Internet: http:// www.ewrs.org/pwc/pdf/2004_Lillehammer_corrected. pdf
Lawson, H.M. 1983. Competition between annual weeds and vining peas grown at a range of population densities: effects on the crop. Weed Research 23: 27-38.

Lepŝ, J. \& Šmilauer, P. 2003. Multivariate analysis of ecological data using CANOCO. Cambridge University Press, Cambridge, UK.

Mela, T. 1988. Luonnonmukainen viljely Suomessa. Viljelymenetelmät, rikkakasvit, peltojen viljavuus, sadot ja sadon laatu. Summary: Organic farming in Finland. Cultivation methods, weeds, soil fertility, yields and yield quality. Helsingin yliopiston kasvinviljelytieteen laitoksen julkaisuja no. 16.220 p.

Ministry of Agriculture and Forestry 2004. Maatilatilastollinen vuosikirja 2004 (Yearbook of farm statistics). SVT Maa-, metsä ja kalatalous 2004: 61. Information Centre of the Ministry of Agriculture and Forestry. 268 p. ISSN 1456-8268.

Mukula, J., Raatikainen, M., Lallukka, R. \& Raatikainen, T. 1969. Composition of weed flora in spring cereals in Finland. Annales Agriculturae Fenniae 8: 59-109.

Økland, R.H. 1999. On the variation explained by ordination and constrained ordination axes. Journal of Vegetation Science 10: 131-136.

Økland, R.H. \& Eilertsen, O. 1994. Canonical correspondence analysis with partitioning: some comments and an application. Journal of Vegetation Science 5: 117-126.

Paatela, J. \& Erviö, L.-R. 1971. Weed seeds in cultivated soils in Finland. Annales Agriculturae Fenniae 10: 144152.

Pessala, B. \& Erviö, L.-R. 1979.Weed control in peas - results in Finland. In: Weeds and weed control 20th Swedish weed conference. Uppsala, Sweden: Sveriges Lantbruksuniversitet. p.106-111.

Poggio, S.L. 2005. Structure of weed communities occurring in monoculture and intercropping of field pea and barley. Agriculture, Ecosystems and Environment 109: 48-58.

Poggio, S.L., Satorre, E.H. \& de la Fuente, E.B. 2004. Structure of weed communities occurring in pea and wheat crops in the Rolling Pampa (Argentina). Agriculture, Ecosystems and Environment 103: 225-235.

Raatikainen, M. \& Raatikainen, T. 1975. Heinänurmien sato, kasvilajikoostumus ja sen muutokset. Summary: Yield, composition and dynamics of flora in grassland for hay in Finland. Annales Agriculturae Fenniae 14: 57-191.

Ruuttunen, P. 1999. Evaluation of herbicides in pea. In: Ruoho, T. (ed.). Trial report - Herbicides and plant growth regulators. MTT Agrifood Research Finland. p. 236-251.

Rydberg, N.T. \& Milberg, P. 2000. A survey of weeds in organic farming in Sweden. Biological Agriculture and Horticulture 18: 175-185.

Salonen, J. 1993. Weed infestation and factors affecting weed incidence in spring cereals in Finland - a multivariate approach. Agricultural Science in Finland 2: 525-536.

Salonen, J., Hyvönen, T. \& Jalli, H. 2001a. Weeds in spring cereal fields in Finland - a third survey. Agricultural and Food Science in Finland 10: 347-364.

Salonen, J., Hyvönen, T. \& Jalli H. 2001b. Weed flora in organically grown spring cereals in Finland. Agricultural and Food Science in Finland 10: 231-242. 
Vol. 14 (2005): 189-201.

SAS Institute Inc. 1999. SAS OnlineDoc $®$, Version 8. SAS Institute Inc., Cary, NC.

Sjursen, H. 2001. Change of the weed seed bank during the first complete six-course crop rotation after conversion from conventional to organic farming. Biological Agriculture and Horticulture 19: 71-90.

Stopes, C. \& Millington, S. 1991. Weed control in organic farming systems. In: Proceedings 1991 Brighton Crop Protection Conference - Weeds. The British Crop Protection Council. p. 185-192. ter Braak C.J.F. \& Šmilauer, P. 1998. CANOCO reference manual and user's guide to Canoco for Windows: Software for Canonical Community Ordination (Version 4). Microcomputer Power, Ithaca, NY, USA.

Uludag, A., Bohren, C., Bulcke, R., Demirci, M., Dobrzanski, A., Froud-Williams, R.J., Hoek, H., Rocha, F., Stagnari, F., Tei, F., Verschwele, A. \& Zaragoza, C. 2003. Weeds and weed management in peas - a review. In: Proceedings 7th EWRS Mediterranean Symposium, Adana, Turkey. p. 15-16.

\title{
SELOSTUS
}

\section{Hernepeltojen rikkakasvit ja niiden torjunta Suomessa}

\author{
Jukka Salonen, Terho Hyvönen ja Heikki Jalli \\ MTT (Maa- ja elintarviketalouden tutkimuskeskus)
}

\begin{abstract}
MTT:n tutkimushankkeeseen "Kotimaista valkuaista herneestä" sisältyi vuosina 2002-2003 hernepeltojen rikkakasvikartoitus Varsinais-Suomessa, Hämeessä, Satakunnassa ja Uudellamaalla. Tutkimustilat valittiin satunnaisesti käyttäen apuna tilastotietoa (MMM/TIKE) herneen viljelyn laajuudesta vuosina 1997-2001. Otantaan sisältyi ruokaherne-, rehuherne- ja seoskasvustoja alueilta, joilla herneen viljelyn yleisyys vaihtelee. Rikkakasvit kartoitettiin, jotta voitaisiin todeta, mitkä rikkakasvilajit ovat yleisimpiä ja runsaimpia herneviljelyksillä, mitkä tekijät vaikuttavat rikkakasvien esiintymiseen ja miten hyvin rikkakasvien torjunta onnistuu kemiallisesti.
\end{abstract}

Vuonna 2002 kartoitettiin 93 peltoa ja vuonna 2003 90 peltoa. Kartoitukseen sisältyi 64 luonnonmukaisesti ja 119 tavanomaisesti viljeltyä peltoa, joiden rikkakasvit määritettiin heinäkuun alussa. Rikkakasvien esiintyminen havainnoitiin viideltä $1 \mathrm{~m}^{2}$ näytealalta käyttäen luokittelevaa peittävyysasteikkoa (0-3). Lajiston koostumuksen vaihtelua ja sitä selittäviä tekijöitä tutkittiin redundanssianalyysin (RDA) avulla.

Hernepelloilta tavattiin yhteensä 76 rikkakasvilajia. Yleisimpiä rikkakasveja olivat jauhosavikka, pillikkeet, pihatähtimö ja pelto-orvokki. Yleisin kestorikkakasvi oli juolavehnä, jota tavattiin $57 \%$ :lla tavanomaisesti viljellyistä ja $75 \%$ :lla luonnonmukaisesti viljellyistä pelloista. Leveälehtisistä kestorikkakasveista peltovalvatti oli yleisempi kuin pelto-ohdake. Hernepeltojen rikkakasvilajisto oli paljolti samanlaista kuin aiemmissa kartoituksissa havaittu kevätviljapeltojen lajisto.

Tuotantomuoto vaikutti rikkakasvilajistoon. Tavanomaisesti viljellyillä pelloilla kasvoi keskimäärin 10 lajia ja luomupelloilla 18 lajia. Luomupeltojen rikkakasvilli- suus koostui pitkälti samoista lajeista, sillä peräti 12 lajia tavattiin yli $70 \%$ :lla tutkituista luomupelloista. Tavanomaisesti viljellyillä hernepelloilla lajisto sen sijaan vaihteli lähinnä sen mukaan, mitä torjunta-ainetta oli käytetty.

Rikkakasvien torjunta-aineista kolme selvästi eniten käytettyä olivat Senkor (metributsiini), Basagran SG (bentatsoni) ja Basagran MCPA (bentatsoni + MCPA). Valmisteiden teho oli yleensä hyvä, mutta herneen rikkakasvien kemiallinen torjunta on kallista esim. viljanviljelyyn verrattuna. Valikoivia juolavehnän torjunta-aineita ruiskutettiin vain seitsemällä pellolla. Mekaanisesti rikkakasveja torjuttiin viidellä luomupellolla.

Suurin vaihtelu lajiston koostumuksessa oli luonnonmukaisesti ja tavanomaisesti viljeltyjen lohkojen välillä. Torjunta-aineiden käyttö ja nurmen esiintyminen viljelykierrossa selittivät myös vaihtelua. Tavanomaisesti viljellyillä pelloilla hernekasvuston ominaisuudet ja torjunta-aineiden käyttö selittivät 38,7 ja 37,6 \% lajiston koostumuksen vaihtelusta. Luomupelloilla hernekasvuston ikä (kylvö- ja näytteenottopäivän välinen erotus) ja pellon sijainti (y-koordinaatti) selittivät 51,7 ja 48,3\% lajiston koostumuksen vaihtelusta.

Hernepeltojen rikkakasveja voidaan torjua tehokkaasti torjunta-aineilla, mutta luomuviljelyssä rikkakasvit ovat ongelma, jonka voisi osittain ratkaista lisäämällä rikkakasvien mekaanista torjuntaa. Seoskasvustojen, esim. herne/kaura, käyttöä suositellaan erityisesti luomuviljelyssä, koska se tehostaa viljelykasvin kilpailua rikkakasveja vastaan. Rikkakasvit eivät aseta merkittäviä esteitä herneen viljelyn laajentumiselle, olkoonkin että niiden torjunta on kallista tavanomaisessa viljelyssä ja haasteellista luomuviljelyssä. 